\title{
Intrahepatic cholangiocarcinoma escapes from growth inhibitory effect of transforming growth factor- $\beta 1$ by overexpression of cyclin D1
}

\author{
Yoh Zen ${ }^{1,2}$, Kenichi Harada ${ }^{1}$, Motoko Sasaki ${ }^{1}$, Tse-Ching Chen ${ }^{3}$, Miin-Fu Chen ${ }^{4}$, \\ Ta-Sen Yeh ${ }^{4}$, Yi-Yin Jan ${ }^{4}$, Shiu-Feng Huang ${ }^{3}$, Yuji Nimura ${ }^{5}$ and Yasuni Nakanuma ${ }^{1}$ \\ ${ }^{1}$ Department of Human Pathology, Kanazawa University Graduate School of Medicine, Kanazawa, Japan; \\ ${ }^{2}$ Department of Pathology, Fukui Saiseikai Hospital, Fukui, Japan; ${ }^{3}$ Department of Pathology, Chang Gung \\ Memorial Hospital, Lin Kou, Taiwan; ${ }^{4}$ Department of Surgery, Chang Gung Memorial Hospital, Lin Kou, \\ Taiwan and ${ }^{5}$ Division of Surgical Oncology, Department of Surgery, Nagoya University Graduate School \\ of Medicine, Nagoya, Japan
}

\begin{abstract}
Transforming growth factor- $\beta 1$ (TGF- $\beta 1$ ) is involved in tumor progression by promoting angiogenesis or suppressing the immune system; yet TGF- $\beta 1$ also has a growth-inhibitory effect on epithelial cells including carcinoma cells. Several mechanisms of impaired TGF- $\beta 1$ responsiveness of carcinoma cells have been reported. In this study, we examined how TGF- $\beta 1$ participates in the development and progression of intrahepatic cholangiocarcinoma (ICC) associated with hepatolithiasis, and how ICC cells escape from growth inhibitory effect of TGF- $\beta 1$. A total of $\mathbf{4 0}$ cases of hepatolithiasis were studied, including 16 cases of ICC, and in vitro studies were conducted with cultured murine non-neoplastic biliary epithelial cells (MBEC) and three ICC cell lines. Immunohistochemically, TGF- $\beta 1$ was expressed in mononuclear cells and mesenchymal cells around the stone-containing bile ducts and invasive ICC, and also in biliary epithelial cells (hyperplastic and precursor lesions, and ICC). TGF- $\beta$ type II receptor (T/R-II) was constantly expressed on biliary epithelial cells irrespective of biliary lesions. In cell culture studies, TGF- $\beta 1$ significantly inhibited proliferation of MBEC via downregulation of cyclin D1, cdk4, and cdk6, while TGF- $\beta 1$ did not influence the proliferation of ICC cells. After suppression of cyclin D1 expression in one ICC cell line using cyclin D1 small interfering RNA, TGF- $\beta 1$ significantly inhibited the proliferation of ICC cells. In conclusion, high levels of TGF- $\beta 1$ around ICC or its precursors may be involved in development and progression of ICC in hepatolithiasis. ICC cells could escape the growth inhibitory effect of TGF- $\beta 1$ by overexpression of cyclin D1.

Laboratory Investigation (2005) 85, 572-581, advance online publication, 7 February 2005; doi:10.1038/labinvest.3700236
\end{abstract}

Keywords: intraductal papillary neoplasm; biliary dysplasia; hepatolithiasis; cell cycle; carcinogenesis

Three isoforms of transforming growth factor- $\beta$ (TGF- $\beta$ ) (TGF- $\beta 1,-\beta 2,-\beta 3$ ) have been identified in humans, and they have similar biological functions. ${ }^{1,2}$ TGF- $\beta$ signal is transducted through two surface receptors, the TGF- $\beta$ type I receptor (T $\beta$ R-I) and the TGF- $\beta$ type II receptor (T $\beta$ R-II), that function as a complex. T $\beta$ R-I and T $\beta$ R-II possess intracellular serine/threonine kinase domains that are activated upon complex formation. ${ }^{3}$ This kinase in

Correspondence: Professor Y Nakanuma, MD, Department of Human Pathology, Kanazawa University Graduate School of Medicine, Kanazawa 920-8640, Japan.

E-mail: pbcpsc@kenroku.kanazawa-u.ac.jp

Received 1 April 2004; revised 4 November 2004; accepted 28 November 2004; published online 7 February 2005 turn initiates an intracellular signal cascade to the nucleus by activation of various proteins, including Smad. ${ }^{4,5}$

Among the TGF- $\beta$ s, TGF- $\beta 1$ has been extensively studied with respect to its involvement in the carcinogenic process. TGF- $\beta 1$ has several advantageous effects for carcinoma cells such as modulating fibrogenesis, angiogenesis, and immune modulation. ${ }^{4,6}$ Overexpression of TGF- $\beta 1$ has been reported in some carcinomas, and is thought to be involved in carcinogenesis and tumor progression. ${ }^{6,7}$ Moreover, overexpression of TGF- $\beta 1$ in carcinoma cells is also known as an influential prognostic factor in breast cancer and lung cancer patients. ${ }^{8,9}$

While TGF- $\beta 1$ has growth inhibitory effects on non-neoplastic epithelial cells, proliferation of most 
carcinoma cells is not influenced by TGF- $\beta 1 .^{1,10}$ This is also the case with cholangiocarcinoma cells. For example, Yokomuro et $a l^{11}$ reported that TGF- $\beta 1$ exerted a concentration-dependent mito-inhibition effect on non-neoplastic biliary epithelium, whereas cholangiocarcinoma cells were resistant to TGF- $\beta 1$. Carcinoma cells are thought to gain resistance to the growth inhibitory effects of TGF- $\beta 1$ by several mechanisms. Somatic mutations of T $\beta$ R-II were firstly reported in some carcinoma cells, especially hereditary nonpolyposis colorectal cancer, ${ }^{12,13}$ though the frequency was found to be relatively low in other carcinomas. ${ }^{14,15}$ Other mechanisms of escaping tumor growth inhibition by TGF- $\beta 1$ such as somatic mutation of Smads, transcriptional downregulation of TGF- $\beta$ receptors, and overexpression of smad7, are also reported. ${ }^{16-19}$

TGF- $\beta 1$ is known to inhibit the proliferation of non-neoplastic epithelium at the G1/S phase via several cell cycle-related molecules such as cyclins (cyclins D, cyclin E), cdks (cdk2, cdk4, cdk6), and cdk inhibitors (p15, p21, p27) ${ }^{20-23}$ TGF- $\beta 1$ executes its growth-inhibitory effect by downregulation of mito-activators (cyclins and cdks) and by upregulation of mito-inhibitors (p15, p21, p27), although the pattern and degree of these effects are different depending on the cell type. Disorganized expression of those cell cycle-related molecules could also induce TGF- $\beta 1$-resistance in some neoplastic cells. ${ }^{24}$ For example, TGF- $\beta 1$ is reported to downregulate expression of cyclin D1, one of the necessary molecules for the transition from the G1 to the S phase of the cell cycle, in non-neoplastic epithelial cells such as rat intestinal epithelial cells. ${ }^{20,23}$ In neoplastic cells, overexpression of cyclin D1 could induce their unresponsiveness to growth inhibitory effect of TGF- $\beta 1 .^{25,26}$ These data suggest that cyclin D1 is thought to be one of the key molecules involved in TGF- $\beta$-unresponsiveness of some carcinoma cells.

In this study, we examined the participation of TGF- $\beta 1$ and T $\beta$ R-II in the development of ICC in hepatolithiasis by immunohistochemistry, by examination of genetic mutations in exons 3,5 , and 7 of the T $\beta$ R-II gene by polymerase chain reaction-single strand conformation polymorphism (PCR-SSCP), and by examination of the relationship between overexpression of cyclin D1 and responsiveness to TGF- $\beta 1$ in cultured cells.

\section{Materials and methods}

\section{Human Tissue Studies}

\section{Patients and materials}

A total of 40 cases of surgically resected hepatolithiasis were obtained from the liver disease file of the Department of Human Pathology, Kanazawa University Graduate School of Medicine, and that of the Department of Pathology, Chang Gung Memorial Hospital, Lin Kou (Table 1). In all, 16 of these cases were associated with ICC (see below). In addition, 'histologically normal' liver tissues were obtained from non-neoplastic parts of five surgically resected metastatic liver tumors.

All of these specimens were fixed in formalin, and embedded in paraffin. All hepatolithiasis cases and five normal liver tissue were used for the immunohistochemistry, and 16 ICC cases were examined for mutational analysis of the T $\beta$ R-II gene.

\section{Classification of biliary lesions associated with hepatolithiasis}

Biliary epithelial lesions of hepatolithiasis were classified into five categories (Table 1): biliary hyperplasia, biliary dysplasia, intraductal papillary neoplasm of the bile duct (IPN-B), ICC with dysplasia, and ICC with IPN-B. All of these biliary lesions were found in the stone-containing intrahepatic large bile ducts, which correspond to the first to third branches of the right and left hepatic ducts. ${ }^{27}$ Biliary dysplasia was defined as flat or micropapillary proliferation of epithelial cells showing multilayering, piled-up nuclei, an increased nucleocytoplasmic ratio, a partial loss of nuclear polarity, and nuclear hyperchromasia and pleomorphism. ${ }^{28}$ IPN-B was defined as prominent papillary proliferation of biliary epithelial cells with distinct fibrovascular cores, showing epithelial nuclear stratification, piled-up nuclei, and nuclear enlargement. ${ }^{29}$ ICC cases were classified into two groups: ICC with dysplasia (nine cases) and ICC with IPN-B (seven cases), in which biliary dysplasia and IPN-B were observed in bile ducts around ICC

Table 1 Liver specimens used for immunohistochemical study and their main clinical features

\begin{tabular}{lcc}
\hline & $\begin{array}{c}\text { Number of cases } \\
\text { examined }\end{array}$ & $\begin{array}{c}\text { Average age } \\
\text { (years) (range) }\end{array}$ \\
\hline Hepatolithiasis (total) & 40 & $55.7(35-74)$ \\
with biliary hyperplasia & 10 & $53.2(35-67)$ \\
with biliary dysplasia & 7 & $54.1(37-69)$ \\
with IPN-B & 7 & $57.1(37-69)$ \\
with ICC and biliary dysplasia & 9 & $56.2(44-74)$ \\
with ICC and IPN-B & 7 & $58.6(53-70)$ \\
Normal bile ducts & 5 & $58.2(52-67)$ \\
\hline
\end{tabular}

IPN-B, intraductal papillary neoplasm of the bile duct; ICC, intrahepatic cholangiocarcinoma. 
lesions (invasive lesions), respectively. ICC with dysplasia was histologically composed of well differentiated (one case), moderately differentiated (six cases), and poorly differentiated adenocarcinoma (two cases), while ICC with IPN-B showed well differentiated papillary adenocarcinoma (two cases), and mucinous carcinoma (five cases).

\section{Immunohistochemistry}

Deparaffinized sections $3 \mu \mathrm{m}$ thick for TGF- $\beta 1$ and $\mathrm{T} \beta \mathrm{R}-\mathrm{II}$ were first treated with hyaluronidase $(2 \mathrm{mg} / \mathrm{ml}$, Sigma Chemical Co., St Louis, MO, USA) for $2 \mathrm{~h}$ at $37^{\circ} \mathrm{C}$. Sections for cyclin D1 were microwaved in EDTA buffer ( $\mathrm{pH}$ 8.0) for $20 \mathrm{~min}$. After blocking of endogenous peroxidase, the sections were incubated in Protein Block Serum (Dako, Glostrup, Denmark) for $20 \mathrm{~min}$, then incubated overnight at $4^{\circ} \mathrm{C}$ with either of primary antibodies: anti-human TGF- $\beta 1$ (clone 9016.2, $5 \mu \mathrm{g} / \mathrm{ml}$, mouse monoclonal, R\&D Systems, Minneapolis, MN, USA), anti-human T $\beta$ R-II $(2 \mu \mathrm{g} / \mathrm{ml}$, gout polyclonal, R\&D Systems), and anti-human cyclin D1 (clone AY-7D2, prediluted, mouse monoclonal, ZYMED Laboratories, San Francisco, CA, USA). These sections were incubated for $1 \mathrm{~h}$ with goat anti-mouse immunoglobulins (TGF- $\beta 1$ and cyclin D1), or rabbit anti-goat immunoglobulins (T $\beta$ R-II), both of which were conjugated to peroxidase labeled polymer (Envision +, Dako; Histofine Simple Stain MAX PO(G), Nichirei, Tokyo, Japan). After 3,3'-diaminobenzidine tetrahydrochloride (DAB) reaction, the sections were lightly counterstained with hematoxylin (TGF- $\beta 1$ and T $\beta$ R-II) or methyl green (cyclin D1). Negative controls were evaluated by nonimmunized mouse or goat serum for primary antibody.

\section{Evaluation of immunohistochemistry}

Expression of TGF- $\beta 1$ and T $\beta$ R-II in individual biliary lesions was evaluated as positive or negative. Expression of cyclin D1 was evaluated by percent of positive cells counted in more than 1000 cells chosen at random in individual case (cyclin D1 labeling index). The labeling index was compared among the biliary lesions.

\section{Mutation screening of the TßR-II gene with PCR-SSCP}

Genomic DNA of ICC (16 cases) was extracted from paraffin tissue using DEXPAD (Takara, Tokyo, Japan). Serial 2- $\mu \mathrm{m}$ paraffin sections of ICC (invasive lesions) were microscopically dissected and mixed with DAXPAD (Takara) at $100^{\circ} \mathrm{C}$ for $10 \mathrm{~min}$. DNA similarly extracted from nontumorous areas of ICC was used as a wild type (nonmutated) control. DNA was obtained by centrifugation and used as a template for PCR.

Three sets of primers were designed to amplify the entire exon sequences for 3,5 , and 7 of the T $\beta$ R-II gene, including each splicing site, as follows: exon 3 , sense $5^{\prime}$-cctcgcttccaatgaatctc- $3^{\prime}$, antisense, $5^{\prime}$-ttggcacagatctcaggtcc- $3^{\prime}$; exon 5 , sense $5^{\prime}$-aatgatggc ctcactgtctg- $3^{\prime}$, antisense $5^{\prime}$-ccactacacatatctggtcc- $3^{\prime}$; exon 7 , sense $5^{\prime}$-cctttggatctctttccogc- $3^{\prime}$, antisense $5^{\prime}$ agaggggcagcctctttgg- $3^{\prime}$. PCR consisted of 40 cycles at $94^{\circ} \mathrm{C}$ for $1 \mathrm{~min}$, at $50^{\circ} \mathrm{C}$ for $2 \mathrm{~min}$, and at $72^{\circ} \mathrm{C}$ for 2 min. Product sizes of exon 3, 5, and 7 were 267, 202 and $249 \mathrm{bp}$, respectively. PCR products were subjected to electrophoresis carried out on acrylamide gels (GeneGel Excel 12.5/24 Kit, Amersham Pharmacia Biotech, Uppsala, Sweden) on GenePhor (Amersham Pharmacia Biotech). The running conditions were $300 \mathrm{~V}$ at $15^{\circ} \mathrm{C}$ for $2 \mathrm{~h}$, and the gels were stained with silver (DNA Silver Staining Kit, Amersham Pharmacia Biotech).

\section{Cell Culture Studies}

\section{Cell culture}

Three human ICC cells (CCKS1, HuCCT1, and $\mathrm{HuH28}$ ) were used in this study. CCKS1. ${ }^{30,31}$ was established in our laboratory, and HuCCT1 ${ }^{32}$ and $\mathrm{HuH} 28^{33}$ were obtained from the Health Science Research Resources Bank (Osaka, Japan). The murine-derived non-neoplastic biliary epithelial cell line (MBEC) was used as control (non-neoplastic biliary epithelial cells), established in our laboratory from intrahepatic large bile duct of an 8-week-old female BALB/c mouse. ${ }^{34}$ A mouse non-noeplastic cell line was used because human-derived nonneoplastic biliary epithelial cells from intrahepatic large bile ducts are difficult to purify and culture with continuous passages.

ICC cells were cultured with medium composed of D-MEM/F-12 (Dulbecco's modified Eagle medium and nutrient mixture F-12, 1:1; Life Technologies, Inc., Rockville, MD, USA), 10\% fetal bovine serum (FBS) (Life Technologies, Inc.), and 1\% antibioticsantimycotic (Life Technologies, Inc.). MBEC were cultured on a collagen-coated dish, and were incubated with a culture medium composed of D-MDM/F-12 (Life Technologies, Inc.), 10\% NuSerum (Becton Dickinson Labware, Bedford, MA, USA), $1 \%$ ITS + (Becton Dickinson Labware), $5 \mu \mathrm{M}$ Forskolin (Wako Pure Chemical Industries, Ltd., Osaka, Japan), $12.5 \mathrm{mg} / \mathrm{ml}$ of Bovine pituitary extract (Life Technologies, Inc.), $1 \mu \mathrm{M}$ dexamethasone (Sigma Chemical Co., St Louis, MO, USA), $5 \mu \mathrm{M}$ triiodothyronine (Sigma Chemical Co.), $5 \mathrm{mg} / \mathrm{ml}$ of Glucose (Sigma Chemical Co.), $25 \mathrm{mM}$ Sodium bicarbonate (Sigma Chemical Co.), 1\% antibiotics-antimycotic (Life Technologies, Inc.) and $25 \mathrm{ng} / \mathrm{ml}$ of mouse epidermal growth factor (Life Technologies, Inc.). These cells were cultured for cell proliferation assay in 96-well plates and also cultured for protein extraction in $60 \mathrm{~mm}$ culture vessels.

Influence of TGF- $\beta 1$ treatment on cell proliferative activities and expression of cell cycle related molecules

ICC cells (CCKS1, HuCCT1, HuH28) and MBEC for proliferation assay were cultured with human 
TGF- $\beta 1$ (Genzyme/Techne, Cambridge, MA, USA) and recombinant TGF- $\beta 1$ (R\&D systems, Inc.) at the concentration of $0.3,3.0$, and $30.0 \mathrm{ng} / \mathrm{ml}$ for $48 \mathrm{~h}$, respectively. Recombinant TGF- $\beta 1$ used in this study was reported to function on murine-derived cell lines. ${ }^{35}$ TGF- $\beta 1$ treatment on cell proliferation study of $\mathrm{HuH} 28$ was started at about $50 \%$ celldensity, because HuH28 had low-proliferative activity (doubling time: 7 days).

Cells for RT-PCR and Western blot analysis were incubated with TGF- $\beta 1$ at a concentration of $3.0 \mathrm{ng} /$ $\mathrm{ml}$ for $48 \mathrm{~h}$. The concentration of $3.0 \mathrm{ng} / \mathrm{ml}$ was determined based on our preliminary research and previous reports. ${ }^{20,21}$

\section{Cell proliferation assay}

Cell proliferation was assayed by CellTiter 96 Aqueous One Solution Cell Proliferation (Promega, Madison, WI, USA). Briefly, $100 \mu \mathrm{l}$ of the cell suspension (containing $1.0 \times 10^{4}$. cells) was plated in each well of 96-well plates. After confirming reattachment of cultured cells, some group of cells were transfected, and were followed by incubation with basic medium or TGF- $\beta 1$ containing medium for $48 \mathrm{~h}$. A amount of $20 \mu \mathrm{l}$ of the CellTiter 96 Aqueous One Solution Reagent was added to each well. After incubation for $3 \mathrm{~h}, 490 \mathrm{~nm}$ absorbance was measured. Five samples for each group were used for analysis.

\section{Western blot}

Proteins were extracted from cultured cells using T-PER $^{\mathrm{TM}}$ Tissue Protein Extraction Reagent (Pierce Chemical Company, Rockford, IL, USA), and were used for Western blot analysis. Western blot analysis was carried out on $10 \%$ SDS-PAGE gel. The proteins in the gel were electrophoretically transferred onto nitrocellulose membrane. The membranes were incubated with primary antibodies to cyclin D1 (clone HD11, 1:100, mouse monoclonal, Santa Cruz Biotechnology, Inc., Santa Cruz, CA, USA), cyclin D2 (clone M-20, 1:100, rabbit polyclonal, Santa Cruz Biotechnology, Inc.), cyclin D3 (clone D-7, 1:100, mouse monoclonal, Santa Cruz Biotechnology, Inc.), cdk2 (clone H-298, 1:200, rabbit polyclonal, Santa Cruz Biotechnology, Inc.), cdk4 (clone H-303, 1:200, rabbit polyclonal, Santa Cruz Biotechnology, Inc.), cdk6 (clone H-96, 1:200, rabbit polyclonal, Santa Cruz Biotechnology, Inc.), T $\beta$ R-II $(2 \mu \mathrm{g} / \mathrm{ml}$, goat polyclonal, R\&D Systems, Inc.), or $\beta$-actin (clone AC-15, 1:5000, mouse polyclonal, Abcam Limited, Cambridge, UK). All of these antibodies were designated for both human and murine research.

Each protein expression was detected using second antibodies conjugated to peroxidase labeled polymers such as Histofine Simple Stain MAX PO (G) (Nichirei) for T $\beta$ R-II and EnVision + system (Dako) for cyclin D1, cyclin D2, cyclin D3, cdk2, cdk4, cdk6, and $\beta$-actin. DAB was used as the chromogen.
Transfection of cyclin D1 small interfering RNA $\mathrm{HuH} 28$, which is a less passaged strain, was selected for small interfering RNA (siRNA) transfection because highly passaged cells are not suited for siRNA transfection. A 21-nucleotide doublestranded RNA was synthesized by B-Bridge International Inc. (San Jose, CA, USA). The targeting sequence of human cyclin D1 was $5^{\prime}$-aagaugaaggagac caucccc- $3^{\prime}$, corresponding to the coding region $334-$ 356 relative to the first nucleotide of the start codon. Scramble siRNA was used as a negative control, which targets the sequence $5^{\prime}$-gcgcgcuuuguagga uucg- $3^{\prime}$. The siRNA were transfected to HuH28 cells with LipofectAMINE PLUS (Invitrogen Corp., Carlsbad, CA, USA). Of $20 \mu \mathrm{M}$ siRNA, $20 \mu \mathrm{l}$ was diluted with $500 \mu \mathrm{l}$ of OPTI-MEM I (Life Technologies, Inc.). An amount of $15 \mu \mathrm{l}$ of PLUS reagent was added to the siRNA, and incubated for $15 \mathrm{~min}$ at room temperature. A volume of $25 \mu \mathrm{l}$ of LipofectAMINE reagent was diluted with $500 \mu$ l of OPTI-MEM I. The two mixtures above were combined, gently mixed, and incubated for $15 \mathrm{~min}$ at room temperature. The entire mixture was added to the $4 \mathrm{ml}$ of culture medium with cells in $6 \mathrm{~mm}$ vessels. A measure of $20 \mu \mathrm{l}$ of this mixture was also added to $100 \mu \mathrm{l}$ of the medium with cells in 96-well plates. At $24 \mathrm{~h}$ after transfection, some groups of cells were treated with TGF- $\beta 1$ as mentioned above. At $72 \mathrm{~h}$ after transfection, the cells were used for the proliferation assay and protein extraction.

\section{Statistical Analysis}

The Mann-Whitney's $U$-test was employed with a significance level of $P<0.05$.

\section{Results}

\section{Human Tissue Studies}

Immunohistochemical detection of TGF- $\beta 1, T \beta R-I I$ and cyclin $D 1$

TGF- $\beta 1$ expression was always detected in the cytoplasm of many inflammatory mononuclear and mesenchymal cells around the intrahepatic large bile duct in hepatolithiasis irrespective of epithelial lesion (Figure 1). TGF- $\beta 1$ expression was also detected in those around invasive ICC. TGF- $\beta 1$ was expressed as a diffuse and granular cytoplasmic staining pattern in hyperplastic biliary epithelium $(70 \%)$, dysplastic epithelium (100\%), IPN-B $(100 \%)$, and ICC with dysplasia $(89 \%)$ or IPN-B $(86 \%)$, and a majority of these epithelial cells were positive, when detected (Figure 2a-c, and Table 2). However, its expression was not observed in normal bile ducts. T $\beta$ R-II was constantly expressed in normal, hyperplastic, dysplastic, and neoplastic (IPN-B and ICC) biliary epithelium in all the cases (Figure 2d-f, and Table 2).

Cyclin D1 was expressed in the nuclei of all cases of biliary dysplasia (range: 4-15\%), IPN-B (2-20\%), 


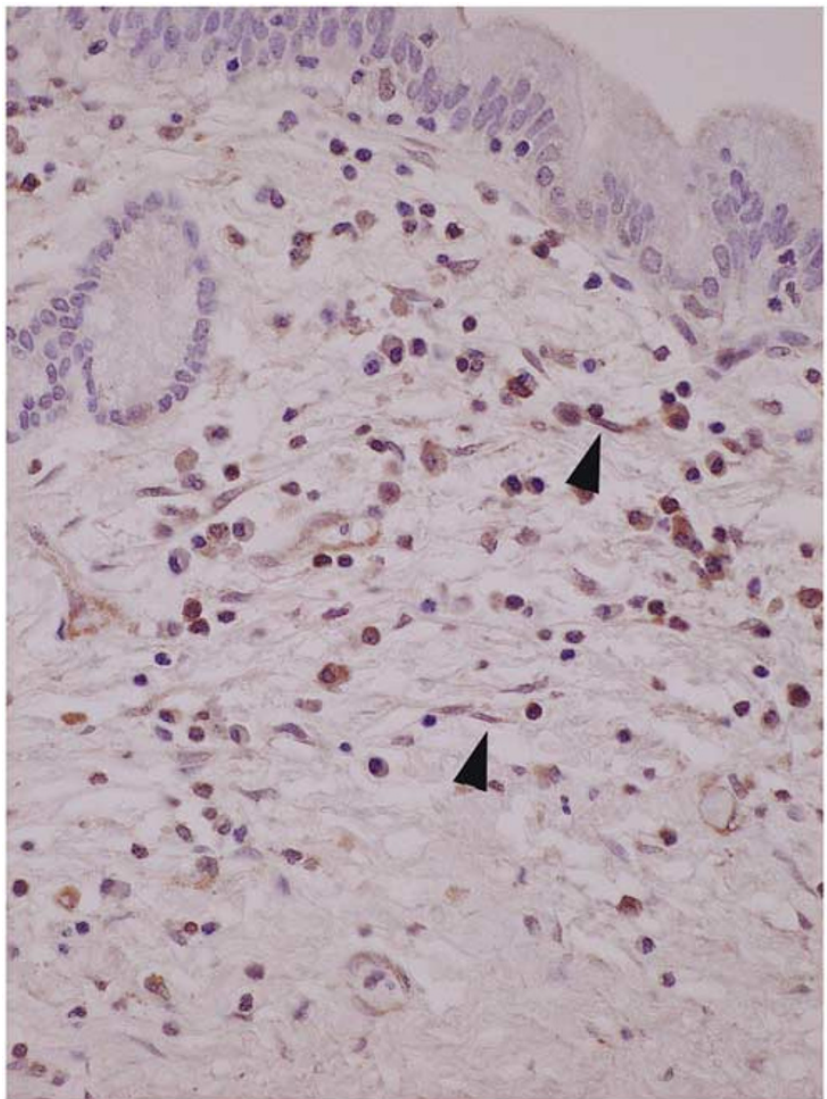

Figure 1 Expression of TGF- $\beta 1$ in the intrahepatic large bile duct of hepatolithiasis. TGF- $\beta 1$ expression is observed in the cytoplasm of many inflammatory mononuclear cells and spindleshaped mesenchymal cells (arrowhead). TGF- $\beta 1$ is not expressed in hyperplastic biliary epithelium in this case. HE, original magnification: $\times 200$.

ICC with dysplasia (5-60\%) and ICC with IPN-B (5-55\%) (Figure 3), but not expressed in normal bile ducts or biliary hyperplasia (Table 3). The labeling index of cyclin D1 was higher in ICC with dysplasia or IPN-B than in biliary dysplasia or IPN-B $(P<0.05)$.

\section{Mutation analysis of the T $\beta R$-II gene in ICC}

Mutations of the T $\beta$ R-II gene in exon 3,5 , and 7 , in which most mutations of T $\beta$ R-II genes are reportedly located, were examined by PCR-SSCP. PCR products included the splicing sites, so all sequences of each exon could be examined and evaluated. The results of SSCP analysis are shown in Figure 4. No shifted bands were observed in the exons of any cases examined or in the no-mutation control (WT), suggesting no genetic mutation existed in the three exons of the 16 ICC cases examined.

\section{Cell Culture Studies}

Influence of TGF- $\beta 1$ on proliferative activities of cultured cells

As shown in Figure 5, TGF- $\beta 1$ treatment showed inhibition on proliferation of MBEC, when com- pared to those without treatment. Treatment with 3.0 and $30.0 \mathrm{ng} / \mathrm{ml}$ of TGF- $\beta 1$ more significantly inhibited the proliferation of MBEC compared to treatment with $0.3 \mathrm{ng} / \mathrm{ml}$ of TGF- $\beta 1$. In contrast, proliferative activities of three cultured ICC cell lines were higher than MBEC, and were not influenced by the treatment of TGF- $\beta 1$ compared to those without treatment. The amount of TGF- $\beta 1$ $(0.3,3.0$, and $30.0 \mathrm{ng} / \mathrm{ml})$ did not influence on the proliferative activities of three ICC cells.

Expression of cell cycle-related molecules in cultured cells by TGF- $\beta 1$ treatment

Western blot analysis of cyclin D1, cyclin D2, cyclin D3, cdk2, cdk4, and cdk6 after treatment of TGF- $\beta 1$ disclosed that the level of cyclin D1 expression was evidently different between MBEC and ICC cells (CCKS1, HuCCT1, and HuH28) (Figure 6). That is, TGF- $\beta 1$ treatment completely inhibited cyclin D1 expression in MBEC, but did not influence cyclin D1 expression in any of ICC cells. TGF- $\beta 1$ also decreased expression of cdk4 (MBEC, and CCKS1 and HuCCT1) and cdk6 (MBEC, and CCKS1 and HuH28). TGF- $\beta 1$ did not influence cyclin D2, cyclin D3, and cdk2 expression in both MBEC and any of three ICC cells.

\section{Influence of TGF- $\beta 1$ on cell proliferative activities} of cultured ICC cells after cyclin D1 siRNA transduction

One ICC cell line (HuH28 cells) transfected with cyclin D1 siRNA showed reduced expression of cyclin D1 protein compared to the nontransfected cells and the cells transfected with scrambled siRNA (negative control) (Figure 7), implying successful transfection of cyclin D1 siRNA followed by the destruction of cyclin D1 RNA. T $\beta$ R-II protein expression was not altered by the transfection of cyclin D1 siRNA or scrambled siRNA (Figure 7).

Transfection of scramble siRNA did not influence cell proliferative activity of HuH28 cells. Transfection of cyclin D1 siRNA resulted in a significant decrease in the cell proliferative activities compared to nontransfected cells and the cells transfected with scrambled siRNA $(P<0.05)$. While the treatment by $0.3 \mathrm{ng} / \mathrm{ml}$ of TGF- $\beta 1$ did not influence proliferative activity of cyclin D1 siRNA-transfected HuH28 cells, 3.0 and $30.0 \mathrm{ng} / \mathrm{ml}$ of TGF- $\beta 1$ significantly inhibited cell proliferation of these cells $(P<0.05)$ (Figure 8). These results indicated that ICC cells acquired responsiveness to TGF- $\beta 1$ by blocking cyclin D1 expression.

\section{Discussion}

It was found in this study that TGF- $\beta 1$ was expressed in mononuclear inflammatory cells and mesenchymal cells around the stone-containing intrahepatic large bile duct in all cases, and also frequently in hyperplastic, dysplastic, and neoplastic (IPN-B and 

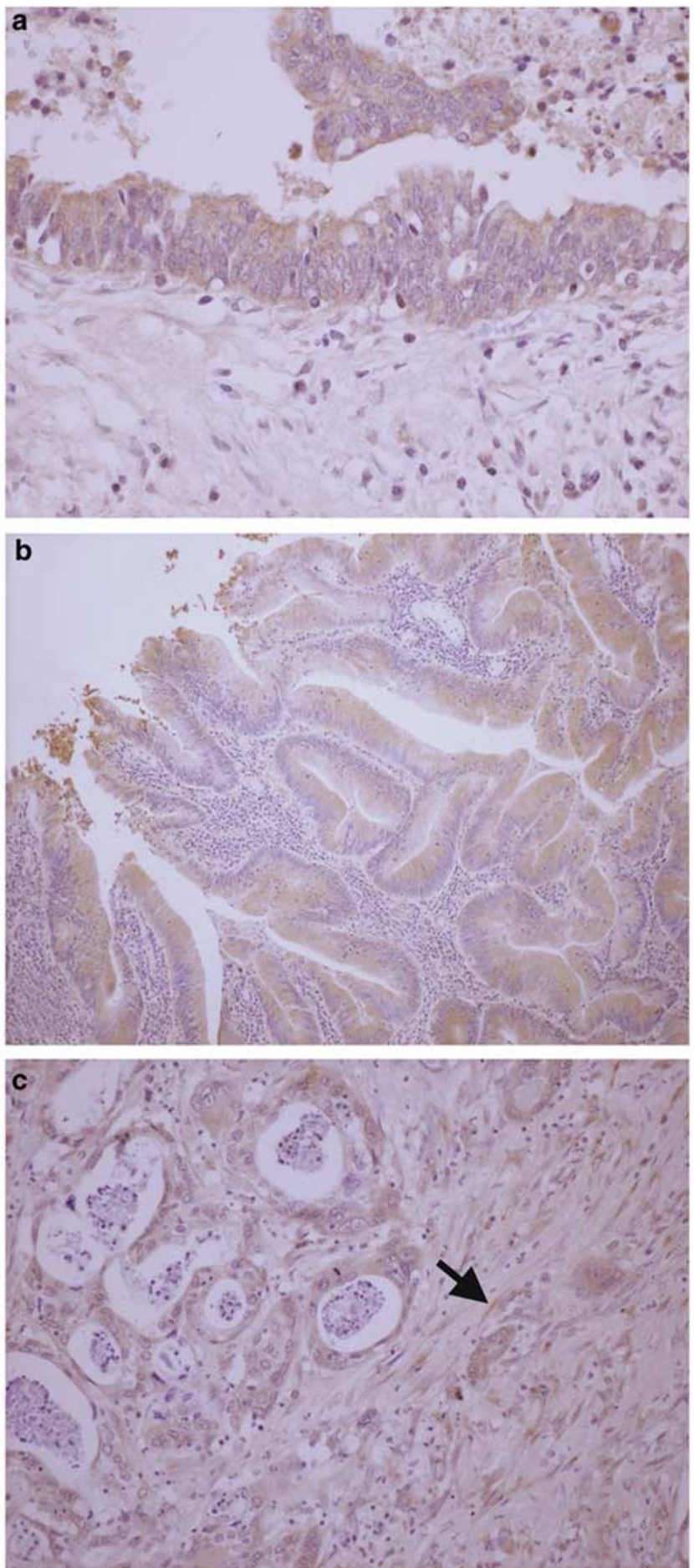
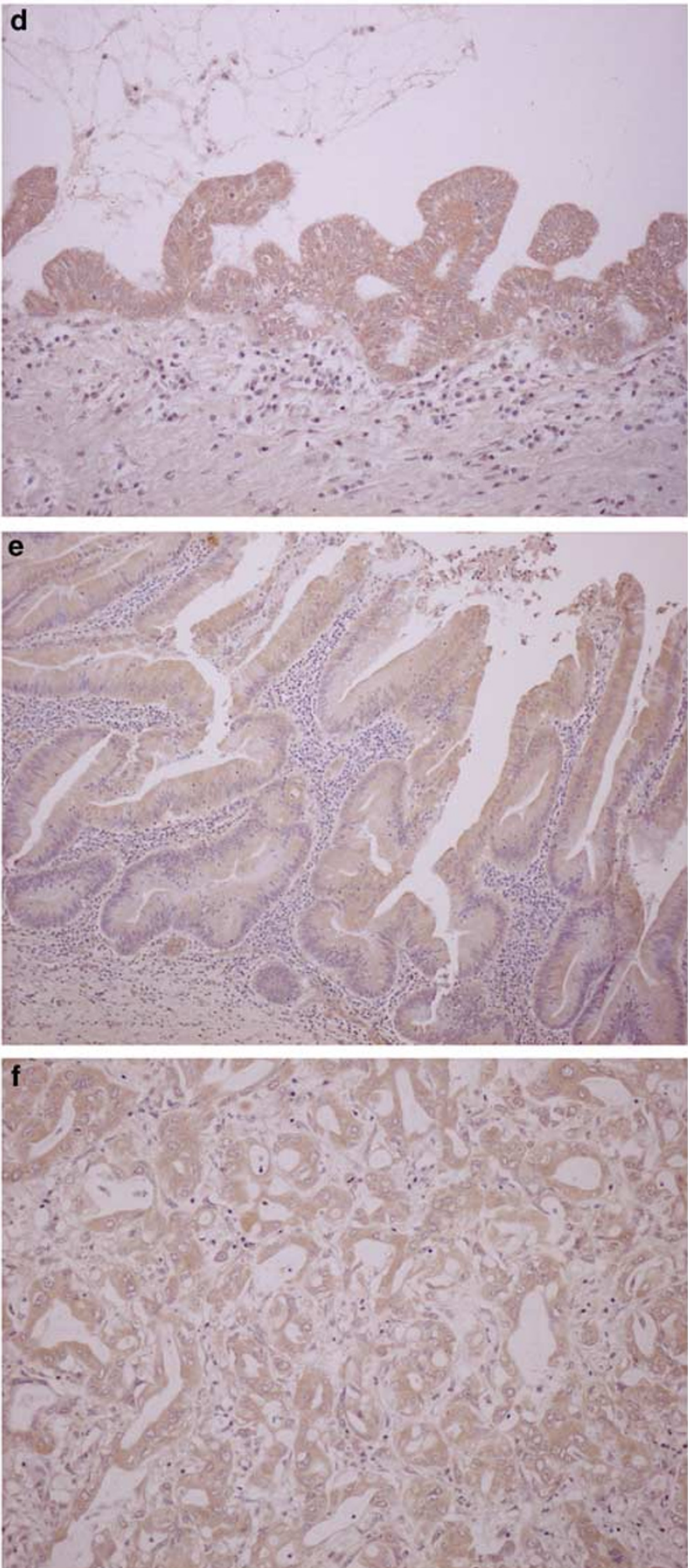

Figure 2 Immunohistochemical expression of TGF- $\beta 1$ (a-c) and T $\beta$ R-II (d-f) on biliary dysplasia (a, d), intraductal papillary neoplasm of the bile duct $(\mathbf{b}, \mathbf{e})$, and ICC (c, f) in hepatolithiasis. (a-c) TGF- $\beta 1$ is expressed in the cytoplasm of biliary epithelial cells of dysplasia, IPN-B, and ICC, and also in mesenchymal cells proliferating around invasive ICC cells (arrow). (d-f) T $\beta$ R-II is expressed in the cytoplasm of biliary epithelial cells of dysplasia, IPN-B, and ICC. Immunostaining counterstained with hematoxylin; original magnification: (a) $\times 400 ;(\mathbf{b}, \mathbf{e}) \times 100 ;(\mathbf{c}, \mathbf{d}, \mathbf{f}) \times 200$.

ICC) biliary epithelial cells. T $\beta$ R-II was constantly expressed in the biliary epithelium (hyperplasia, dysplasia, IPN-B, and ICC). These results suggested that TGF- $\beta 1$ liberated from inflammatory and mesenchymal cells and also from biliary epithelial cells 
Table 2 Immunohistochemical expression of TGF- $\beta 1$ and T $\beta$ R-II by the epithelium of normal bile ducts, biliary hyperplasia, IPN-B, and ICC

\begin{tabular}{|c|c|c|c|c|}
\hline & \multicolumn{2}{|c|}{$T G F-\beta 1$} & \multicolumn{2}{|c|}{$T \beta R-I I$} \\
\hline & Positive & Negative & Positive & Negative \\
\hline Normal bile ducts $(n=5)$ & 0 & $5(100 \%)$ & $5(100 \%)$ & 0 \\
\hline Biliary hyperplasia $(n=10)$ & $7(70 \%)^{*}$ & $3(30 \%)$ & $10(100 \%)$ & 0 \\
\hline Biliary dysplasia $(n=7)$ & $7(100 \%) *$ & 0 & $7(100 \%)$ & 0 \\
\hline IPN-B $(n=7)$ & $7(100 \%)^{*}$ & 0 & $6(100 \%)$ & 0 \\
\hline ICC with biliary dysplasia $(n=9)$ & $8(89 \%)^{*}$ & $1(11 \%)$ & $9(100 \%)$ & 0 \\
\hline ICC with IPN-B $(n=7)$ & $6(86 \%)^{*}$ & $1(14 \%)$ & $7(100 \%)$ & 0 \\
\hline
\end{tabular}

$N$, number of cases examined: T $\beta$ R-II, TGF- $\beta$ type II receptor; IPN-B, intraductal papillary neoplasm of the bile duct; ICC, intrahepatic cholangiocarcinoma; ${ }^{*} P<0.05$ vs normal bile duct.

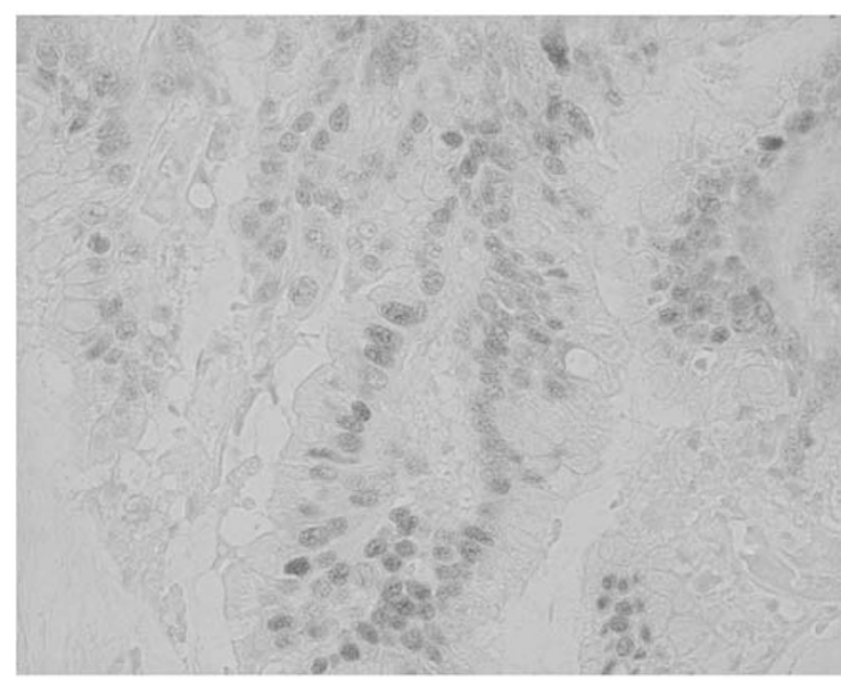

Figure 3 Cyclin D1 is expressed in nuclei of ICC in hepatolithiasis. Immunostaining of cyclin D1 counterstained with methyl green; original magnification, $\times 400$.

Table 3 Cyclin D1 expression (labeling index) on normal bile ducts, biliary hyperplasia, IPN-B, and ICC

\begin{tabular}{lc}
\hline Bile duct lesions & $\begin{array}{c}\text { Labeling index (\%) } \\
\text { Average } \pm \text { s.d. (range) }\end{array}$ \\
\hline Normal bile ducts $(n=5)$ & $0 \pm 0 \%(0-0)$ \\
Biliary hyperplasia $(n=10)$ & $0 \pm 0 \%(0-0)$ \\
Biliary dysplasia $(n=7)$ & $7.9 \pm 3.5 \%(4-15 \%)^{*}$ \\
IPN-B $(n=7)$ & $5.7 \pm 2.6 \%(2-20 \%)^{*}$ \\
ICC with biliary dysplasia $(n=9)$ & $29.3 \pm 20.4 \%(5-60 \%)^{* *}$ \\
ICC with IPN-B $(n=7)$ & $23.1 \pm 17.0 \%(5-55 \%)^{* *}$
\end{tabular}

Labeling index of cyclin D1, percent of positive cells in more than 1000 cells examined; $n$, number of cases examined; s.d., standard deviation; IPN-B, intraductal papillary neoplasm of the bile duct; ICC, intrahepatic cholangiocarcinoma; ${ }^{*} P<0.05$ vs normal bile ducts and biliary hyperplasia; ${ }^{*} P<0.05$ vs normal bile duct, biliary hyperplasia, biliary dysplasia, and IPN-B.

advantageous effects for ICC and its precursors such as angiogenesis, fibrosis, and suppression of immune system.

We then performed in vitro studies to determine how TGF- $\beta 1$ influences cell proliferation of non-

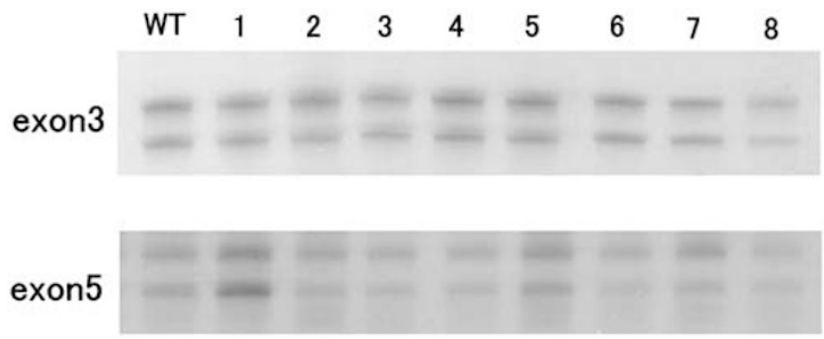

exon7

Figure 4 Mutational analysis of the T $\beta$ R-II gene. PCR-SSCP of exon 3 , exon 5 , and exon 7 of T $\beta$ R-II shows no shifted band in any exons. Eight samples of ICC (numbered 1-8) in hepatolithiasis are shown. WT is a wild-type control from the non-neoplastic part of the liver.

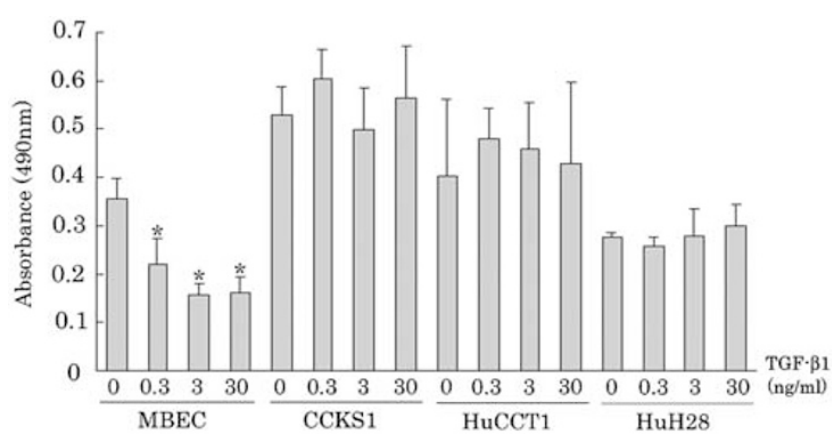

Figure 5 Proliferation assay of cultured MBEC and human ICC cells (CCKS1, HuCCT1, HuH28) after the treatment with TGF- $\beta 1$ $(0.3,3.0,30.0 \mathrm{ng} / \mathrm{ml})$. Treatment with TGF- $\beta 1$ significantly inhibited the proliferation of MBEC, while treatment with TGF$\beta 1$ did not change the proliferation activity of the ICC cells. Data are shown as mean + standard deviation. ${ }^{*} P<0.05$ vs MBEC without TGF- $\beta 1$ treatment.

neoplastic and neoplastic biliary epithelial cells and examine the potential molecular mechanisms. We found that TGF- $\beta 1$ significantly inhibited the proliferation of MBEC, in which downregulation of cyclin D1, cdk4, and cdk6 might be causally 


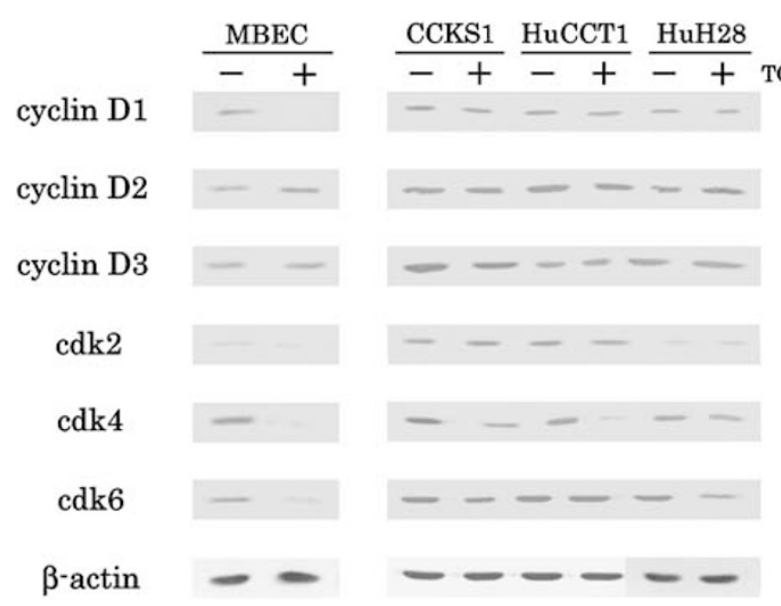

Figure 6 Protein expression of cyclin D1, cyclin D2, cyclin D3, cdk2, cdk4, and cdk6 in cultured MBEC and human ICC cells (CCKS1, HuCCT1, HuH28) with and without TGF- $\beta 1$ treatment $(3.0 \mathrm{ng} / \mathrm{ml}, 48 \mathrm{~h})$. TGF- $\beta 1$ inhibits expression of cyclin D1, cdk4 and cdk6 in MBEC. TGF- $\beta 1$ also inhibits expression of cdk4 (CCKS1, HuCCT1) and cdk6 (CCKS1, HuH28) in ICC cells, while cyclin D1 expression is not influenced by TGF- $\beta 1$ treatment in ICC cells.

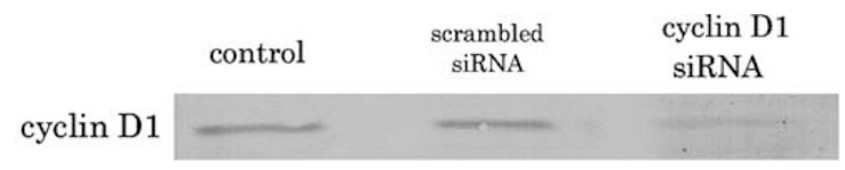

\section{T $\beta R-I$}

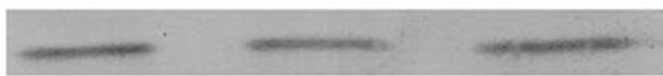

\section{$\beta$-actin}

Figure 7 Protein expression of cyclin D1 and T $\beta$ R-II in HuH28 cell after transfection of cyclin D1 siRNA or scramble siRNA. Westen blot analysis of cyclin D1 revealed that cyclin D1 expression was inhibited by transfection with cyclin D1 siRNA, while it was not inhibited by transfection of scramble siRNA. $\mathrm{T} \beta \mathrm{R}$-II expression was not influenced by transfection of cyclin D1 siRNA or scramble siRNA.

involved. On the other hand, TGF- $\beta 1$ did not influence the cell-proliferative activities of three cultured human ICC cells. Cyclin D1 expression remained unchanged, even though cdk4 and cdk6 were downregulated. Accordingly, we demonstrated that siRNA inhibition of cyclin D1 expression rendered one ICC cell line sensitive to growthinhibitory effect of TGF- $\beta 1$. These results strongly suggested that overexpression of cyclin D1 is a key event for ICC cells attaining TGF- $\beta 1$-resistance. Indeed, overexpression of cyclin D1 was immunohistochemically detected variably in the nuclei of all cases of biliary dysplasia, IPN-B, ICC with dysplasia or IPN-B, while cyclin D1 was not detectable in biliary hyperplasia or normal bile ducts. Interestingly the labeling index of cyclin D1 was higher in ICC cases than in its precursors (dysplasia and IPNB), suggesting that overexpression of cyclin D1 is

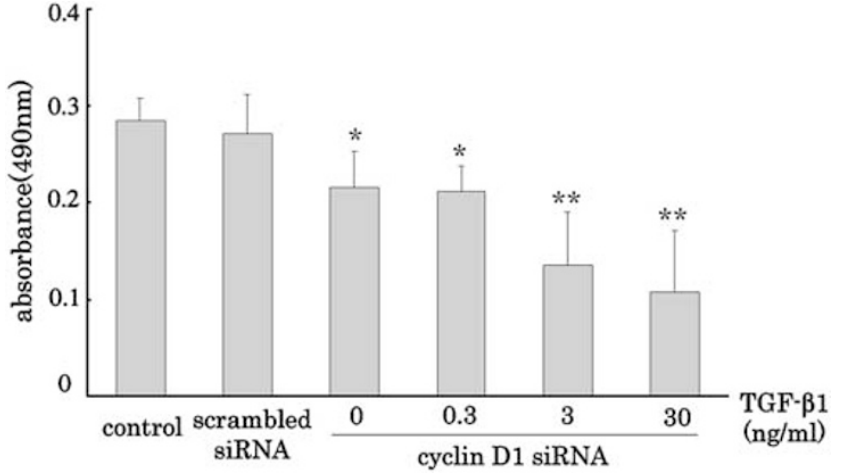

Figure 8 Proliferation assay of cultured human ICC cells (HuH28) transfected with cyclin D1 siRNA after treatment with TGF- $\beta 1$ $(0.3,3.0,30.0 \mathrm{ng} / \mathrm{ml})$. Proliferation of cyclin D1 siRNA-transfected cells was significantly inhibited compared to control cells and scramble siRNA-transfected cells. While TGF- $\beta 1(0.3 \mathrm{ng} / \mathrm{ml})$ could not influence the proliferation activity, TGF- $\beta 1(3.0,30.0 \mathrm{ng} / \mathrm{ml})$ significantly inhibited the proliferation of cyclin D1 siRNAtransfected cells. Data are shown as mean + standard deviation. ${ }^{*} P<0.05$ vs control cells and scramble siRNA-transfected cells; ${ }^{*} P<0.05$ vs cyclin D1 siRNA-transfected cells without TGF- $\beta 1$ treatment.

involved in the development and progression of ICC arising in hepatolithiasis.

A similar mechanism for TGF- $\beta$-resistance via cyclin D1 overexpression was also reported in human hepatocellular carcinoma (HCC) cells and immortalized human esophageal epithelial cell..$^{25,26}$ Jong et $a l^{25}$ reported that HCC cell lines, which were resistant to TGF- $\beta 1$, showed overexpression of cyclin D1, and the suppression of cyclin D1 expression with antisense cyclin D1 facilitated the growth inhibitory effect of TGF- $\beta 1$. In addition, Okamoto et $a l^{26}$ reported that immortalized human esophageal epithelial cells became resistant to TGF$\beta 1$ after transfection of human cyclin D1 cDNA. Interestingly, transfection of cyclin D1 gene downregulated T $\beta$ R-II expression in that esophageal epithelial cell line. Okamoto et $a l^{26}$ suggested that cyclin D1 overexpression followed by downregulation of T $\beta$ R-II might be a key event for those esophageal epithelial cells to obtain TGF- $\beta 1$-resistance. In this study, transfection of cyclin D1 siRNA did not influence the expression of $\mathrm{T} \beta \mathrm{R}$-II in ICC cells (HuH28), suggesting no close relationship between cyclin D1 expression and T $\beta$ R-II expression in ICC cells.

In hepatolithiasis, ICC and its precursor lesions are not infrequently encountered, ${ }^{36,37}$ and ICC in hepatolithiasis is thought to develop through multistep carcinogenesis. ${ }^{38}$ At present, at least two pathways of multistep cholangiocarcinogenesis are speculated in hepatolithiasis. The first pathway may be a major pathway through biliary dysplasia showing flat or micropapillary lesion to invasive ICC, usually conventional tubular or papillary adenocarcinoma. ${ }^{38}$ Another is a unique carcinogenetic pathway from IPN-B to invasive ICC. ${ }^{29}$ IPN-B is a recently proposed disease entity, and is characterized as prominent 
papillary proliferation of biliary epithelial cells with gastrointestinal metaplasia and mucin over-production, frequent association with mucinous carcinoma if progressed to invasive cancer, and more favorable prognosis compared to conventional ICC. ${ }^{39,40}$ There is now increasing evidence that different genetic abnormalities exist between these two carcinogenetic pathways. ${ }^{41,42}$ While no differences in expression of TGF- $\beta 1, \mathrm{~T} \beta \mathrm{R}-\mathrm{II}$, and cyclin $\mathrm{D} 1$, and also genetic mutation of T $\beta$ R-II were observed between these two precursor lesions and resultant ICC, a potential weakness of this study was that in vitro study was conducted using only human ICC cell lines derived from conventional ICC. So far, cultured cell lines derived from IPN-B or ICC with IPN$B$ have not been established.

$\mathrm{T} \beta \mathrm{R}$-II was constantly expressed in biliary epithelial cells regardless of atypical degree in 40 cases examined. It was found in this study that no genetic mutations were detectable in exon 3,5 , or 7 of the T $\beta$ R-II gene in 16 ICC cases. Most mutations of the T $\beta$ R-II gene reported so far are located in exon 3, 5, and $7 .{ }^{43}$ As microsatellite regions exist in exon 3 and 7 of the T $\beta$ R-II gene, ${ }^{44}$ somatic mutations in these regions may relate to microsatellite instability or replication error. ${ }^{45,46}$ Mutations in exon 5 are sporadic and are not associated with replication error. ${ }^{43}$ Somatic mutations of T $\beta$ R-II are noticeable in hereditary nonpolyposis colorectal cancer, although these mutations are less frequent in most carcinomas without microsatellite instability. ${ }^{14,15}$ Taken together, it seems likely that mutation of exon 3,5 , and 7 of T $\beta$ R-II is a minor mechanism for TGF- $\beta$-resistance in ICC cells.

In conclusion, overexpressed TGF- $\beta 1$ around ICC and its precursor lesions may exert several advantageous effects for them and be involved in cholangiocarcinogenesis in hepatolithiasis. ICC cells could escape the growth inhibitory effect of TGF- $\beta 1$ by overexpression of cyclin D1.

\section{Acknowledgements}

This work was supported in part by Grants-in-Aid for Intrahepatic Calculi from the Ministry of Health and Welfare, Japan.

\section{References}

1 Massague J. The transforming growth factor-beta family. Annu Rev Cell Biol 1990;6:597-641.

2 Kingsley DM. The TGF-beta superfamily: new members, new receptors, and new genetic tests of function in different organisms. Genes Dev 1994;8:133-146.

3 Wrana JL, Attisano L, Wieser R, et al. Mechanism of activation of the TGF-beta receptor. Nature 1994;370: 341-347.

4 Derynck R, Akhurst RJ, Balmain A. TGF-beta signaling in tumor suppression and cancer progression. Nat Genet 2001;29:117-129.
5 Miyazono K. Positive and negative regulation of TGF-beta signaling. J Cell Sci 2000;113:1101-1109.

6 Lohr M, Schmidt C, Ringel J, et al. Transforming growth factor-beta1 induces desmoplasia in an experimental model of human pancreatic carcinoma. Cancer Res 2001;61:550-555.

7 Bellone G, Carbone A, Tibaudi D, et al. Differential expression of transforming growth factors-beta1, -beta2 and -beta 3 in human colon carcinoma. Eur J Cancer 2001;37:224-233.

8 Hasegawa Y, Takanashi S, Kanehira Y, et al. Transforming growth factor-beta1 level correlates with angiogenesis, tumor progression, and prognosis in patients with nonsmall cell lung carcinoma. Cancer 2001;91: 964-971.

9 Ghellal A, Li C, Hayes M, et al. Prognostic significance of TGF beta 1 and TGF beta 3 in human breast carcinoma. Anticancer Res 2000;20:4413-4418.

10 Norgaard P, Hougaard S, Poulsen HS, et al. Transforming growth factor beta and cancer. Cancer Treat Rev 1995;21:367-403.

11 Yokomuro S, Tsuji H, Lunz III JG, et al. Growth control of human biliary epithelial cells by interleukin 6, hepatocyte growth factor, transforming growth factor beta1, and activin A: comparison of a cholangiocarcinoma cell line with primary cultures of nonneoplastic biliary epithelial cells. Hepatology 2000;32: 26-35.

$12 \mathrm{Lu}$ SL, Zhang WC, Akiyama Y, et al. Genomic structure of the transforming growth factor beta type II receptor gene and its mutations in hereditary nonpolyposis colorectal cancers. Cancer Res 1996;56: 4595-4598.

13 Lu SL, Akiyama Y, Nagasaki H, et al. Mutations of the transforming growth factor-beta type II receptor gene and genomic instability in hereditary nonpolyposis colorectal cancer. Biochem Biophys Res Commun 1995;216:452-457.

14 Goggins M, Shekher M, Turnacioglu K, et al. Genetic alterations of the transforming growth factor beta receptor genes in pancreatic and biliary adenocarcinomas. Cancer Res 1998;58:5329-5332.

15 Francis-Thickpenny KM, Richardson DM, van Ee CC, et al. Analysis of the TGF beta functional pathway in epithelial ovarian carcinoma. Br J Cancer 2001;85: 687-691.

16 Riggins GJ, Kinzler KW, Vogelstein B, et al. Frequency of Smad gene mutations in human cancers. Cancer Res 1997;57:2578-2580.

17 Takagi Y, Koumura H, Futamura M, et al. Somatic alterations of the SMAD-2 gene in human colorectal cancers. Br J Cancer 1998;78:1152-1155.

18 Paterson IC, Matthews JB, Huntley S, et al. Decreased expression of TGF-beta cell surface receptors during progression of human oral squamous cell carcinoma. J Pathol 2001;193:458-467.

19 Zhang T, Nanney LB, Peeler MO, et al. Decreased transforming growth factor beta type II receptor expression in intestinal adenomas from Min/+ mice is associated with increased cyclin D1 and cyclindependent kinase 4 expression. Cancer Res 1997;57: 1638-1643.

20 Ko TC, Sheng HM, Reisman D, et al. Transforming growth factor-beta 1 inhibits cyclin D1 expression in intestinal epithelial cells. Oncogene 1995;10:177-184.

21 Geng Y, Weinberg RA. Transforming growth factor beta effects on expression of G1 cyclins and cyclin- 
dependent protein kinases. Proc Natl Acad Sci USA 1993;90:10315-10319.

22 Ravitz MJ, Wenner CE. Cyclin-dependent kinase regulation during G1 phase and cell cycle regulation by TGF-beta. Adv Cancer Res 1997;71:165-207.

23 Carneiro C, Alvarez CV, Zalvide J, et al. TGF-beta1 actions on FRTL-5 cells provide a model for the physiological regulation of thyroid growth. Oncogene 1998;16:1455-1465.

$24 \mathrm{Hu}$ X, Zhang X, Zhong Q, et al. Differential effects of transforming growth factor on cell cycle regulatory molecules in human myeloid leukemia cells. Oncogene 2001;20:6840-6850.

25 Jong HS, Lee HS, Kim TY, et al. Attenuation of transforming growth factor beta-induced growth inhibition in human hepatocellular carcinoma cell lines by cyclin D1 overexpression. Biochem Biophys Res Commun 2002;292:383-389.

26 Okamoto A, Jiang W, Kim SJ, et al. Overexpression of human cyclin D1 reduces the transforming growth factor beta (TGF-beta) type II receptor and growth inhibition by TGF-beta 1 in an immortalized human esophageal epithelial cell line. Proc Natl Acad Sci USA 1994;91:11576-11580.

27 Nakanuma Y, Hoso M, Sanzen T, et al. Microstructure and development of the normal and pathologic biliary tract in humans, including blood supply. Microsc Res Techn 1997;38:552-570.

28 Nakanuma Y, Sripa B, Vatanasapt V, et al. Intrahepatic cholangiocarcinoma. In: Hamilton SR, Aaltonen LA (eds). WHO Classification of Tumors, Pathology and Genetics, Tumors of Digestive System. IARC Press: Lyon, France, 2000, pp. 173-180.

29 Chen TC, Nakanuma Y, Zen Y, et al. Intraductal papillary neoplasia of the liver associated with hepatolithiasis. Hepatology 2001;34:651-658.

30 Saito K, Minato H, Kono N, et al. Establishment of the human cholangiocellular carcinoma cell line (CCKS1). Kanzo 1993;34:122-129.

31 Sugawara H, Yasoshima M, Katayanagi K, et al. Relationship between interleukin-6 and proliferation and differentiation in cholangiocarcinoma. Histopathology 1998;33:145-153.

32 Miyagiwa M, Ichida T, Tokiwa T, et al. A new human cholangiocellular carcinoma cell line (HuCC-T1) producing carbohydrate antigen $19 / 9$ in serum-free medium. In Vitro Cell Dev Biol 1989;25:503-510.

33 Kusaka Y, Tokiwa T, Sato J. Establishment and characterization of a cell line from a human cholangiocellular carcinoma. Res Exp Med (Berl) 1988;188: 367-375.

34 Katayanagi K, Kono N, Nakanuma Y. Isolation, culture and characterization of biliary epithelial cells from different anatomical levels of the intrahepatic and extrahepatic biliary tree from a mouse. Liver 1998;18:90-98.

35 Tsang ML, Zhou L, Zheng BL, et al. Characterization of recombinant soluble human transforming growth factor-beta receptor type II (rhTGF-beta sRII). Cytokine 1995;7:389-397.

36 Nakanuma Y, Terada T, Tanaka Y, et al. Are hepatolithiasis and cholangiocarcinoma aetiologically related? A morphological study of 12 cases of hepatolithiasis associated with cholangiocarcinoma. Virchows Arch A Pathol Anat Histopathol 1985;406: 45-58.

37 Chen MF, Jan YY, Hwang TL, et al. Impact of concomitant hepatolithiasis on patients with peripheral cholangiocarcinoma. Dig Dis Sci 2000;45: 312-316.

38 Terada T, Nakanuma Y, Ohta T, et al. Histological features and interphase nucleolar organizer regions in hyperplastic, dysplastic and neoplastic epithelium of intrahepatic bile ducts in hepatolithiasis. Histopathology 1992;21:233-240.

39 Shimonishi $\mathrm{T}$, Zen Y, Chen TC, et al. Increasing expression of gastrointestinal phenotypes and p53 along with histologic progression of intraductal papillary neoplasia of the liver. Hum Pathol 2002;33: 503-511.

40 Chen MF, Jan YY, Chen TC. Clinical studies of mucinproducing cholangiocellular carcinoma: a study of 22 histopathology-proven cases. Ann Surg 1998;227: 63-69.

41 Abraham SC, Lee JH, Hruban RH, et al. Molecular and immunohistochemical analysis of intraductal papillary neoplasms of the biliary tract. Hum Pathol 2003;34:902-910.

42 Abraham SC, Lee JH, Boitnott JK, et al. Microsatellite instability in intraductal papillary neoplasms of the biliary tract. Mod Pathol 2002;15:1309-1317.

43 Vincent F, Nagashima M, Takenoshita S, et al. Mutation analysis of the transforming growth factor-beta type II receptor in human cell lines resistant to growth inhibition by transforming growth factor-beta. Oncogene 1997;15:117-122.

44 Takenoshita S, Hagiwara K, Nagashima M, et al. The genomic structure of the gene encoding the human transforming growth factor beta type II receptor (TGFbeta RII). Genomics 1996;36:341-344.

45 Furuta K, Misao S, Takahashi K, et al. Gene mutation of transforming growth factor beta1 type II receptor in hepatocellular carcinoma. Int J Cancer 1999;81: 851-853.

46 Parsons R, Myeroff LL, Liu B, et al. Microsatellite instability and mutations of the transforming growth factor beta type II receptor gene in colorectal cancer. Cancer Res 1995;55:5548-5550. 